\section{Afinidades comunicativas e as políticas de saúde no Brasil}

Communicative relationships and health policies in Brazil

\section{Ligia Bahia ${ }^{4}$}

Transpira ação comunicativa da extensa e aprofundada análise de Javier Uribe Rivera e Elizabeth Artmann sobre o planejamento e a gestão em saúde. Apreende-se do trabalho a existência de uma nova geração de planejadores que compartilham teorias e práticas que acentuam a "inclusividade”, a interação, os esforços intersubjetivos para compreensão mútua. Aprende-se com o estudo apresentado que a abordagem do planejamento estratégico comunicativo, criteriosamente aplicada na investigação de um campo de conhecimento e saberes, resulta numa descoberta comunicativa. Possuímos grupos consolidados de pesquisa e soubemos não apenas valorizar, como também absorver criticamente as tendências de substituição do modelo de planejamento tecnocrático por enfoques mais sensíveis aos desafios da vida contemporânea.

Trata-se de uma "comunicação à academia" narrada por sujeitos inerentemente implicados com seus desdobramentos. Essa fórmula interativa inverte àquela do discurso de Pedro, o personagem de Kafka que relata, com imenso sofrimento, a cientistas, seu processo de transformação em homem. Os autores, misturados e comprometidos com o movimento de aprimorar, pensar, poder e fazer planejamento, detectam amplas, plurais, potentes e renovadas redes interconectadas pelas interfaces entre planejamento e gestão.

Essas evidências sobre o vasto acervo de conhecimentos sobre planejamento e gestão em saúde e, sobretudo, os registro das inquietações teórico-metodológicas da área, são relevantes e oportunas. Para quem supunha uma geração quase espontânea da peculiar intelligentsia do SUS, fica suficientemente comprovada a importância de uma permanente fonte de nutrição de conhecimentos e intervenção sobre o sistema de saúde, encarado como construção social. Além disso, o desvelamento das ricas tramas e matizes subjacentes ao tecimento das conexões entre planejamento e gestão ocorre num momento extremamente propício.

O declínio da onda neoliberal vem arrastando consigo as representações quantificadas e reducionistas de mundo e repondo temas filosófi- cos e políticos centrais nas agendas públicas. Tomando de empréstimo definições de Foucault ${ }^{1}$, pode-se dizer que a reconvocação dos saberes baseados nas narrativas, nos testemunhos, na observação estimula alternativas de planejamento baseadas na compreensão das ações de agentes para a organização da sociedade. Consequentemente, é muito promissor contar com reflexões sobre os modelos de planejamento em saúde no Brasil sedimentadas pelo diálogo com as vertentes internacionais.

Mas, a concordância no plano mais geral sobre as relações entre a pujança do estado da arte do conhecimento sobre os temas planejamento e gestão em saúde e os paradigmas comunicacionais, colaborativos, participativos, suscita interrogações exatamente sobre os fundamentos ativados na construção de futuros. E, para esclarecê-las adequadamente, é preciso adiantar que não há dúvidas sobre a pluralidade de perspectivas sobre saúde, quer na esfera cultural, social, econômica e política.

Superamos a caracterização pobre do Estado como inimigo autoritário ou como o único ator que planeja. Tampouco é plausível associar univocamente democracia, participação e resultados justos. A questão, portanto, é como a "guinada comunicativa" do planejamento contribui para a efetivação de reconhecimento de situações de compartilhamento de poder e situações de disputa de poder?

A desmistificação pretendida pela substituição da exortação retórica do planejamento tradicional pela análise para a ação não pode deixar de lado a presença de conflitos estruturais e correlações de forças assimétricas. Nem os relatos e a escuta atenta e a negociação de expectativas sobre como, quando, porque e o que fazer daqueles envolvidos numa dada situação se transformam necessariamente em explicações sobre a realidade. Nem a possibilidade da mudança de ideias de agentes que ocupam posições-chave implica transformação estrutural. Os equívocos cognitivos tais como a identificação automática de empresários da saúde como os únicos vilões da história e a realocação precipitada de um ator, que adere a valores progressistas, num quadrante oposto ao anterior, constrangerão a prática política.
${ }^{4}$ Universidade Federal do Rio de Janeiro. ligiabahia@terra.com.br 
Mais preocupante ainda é a não explicitação dos lugares de onde falam os planejadores em saúde. Quase sempre vinculados às instituições governamentais e instados a intermediar, traduzir interesses diferenciados, os planejadores tendem a obscurecer tanto os problemas afetos às burocracias governamentais como também aqueles supostamente atribuídos a uma esfera econômica externa às organizações de saúde. Fatos como as ambulâncias do SAMU não atenderem em áreas de risco (consideradas violentas), a presença ostensiva de representantes de indústrias nos hospitais públicos, diversas formas de cobrança indireta do atendimento e os esquemas que subtraem horas de trabalho de profissionais de saúde e as intervenções políticas na designação de cargos, inclusive dos planejadores, que normatizam informalmente a ação, não são, quase nunca, associados aos desafios de coordenação e integração do sistema de saúde.

Como reduzir o "espaço do segredo" do qual, para Bobbio ${ }^{2}$, depende o vigor de uma sociedade pluralista? A separação da democracia de sua dimensão normativa prevê que uma ordem se estabeleça pelo compromisso entre interesses e valores diversos. Entretanto, como nos ensina Javier, a racionalidade comunicativa não é tão somente instrumental, envolve questões pertinentes ao conceito de verdade ${ }^{3}$. Logo, existe uma inequívoca separação entre o mero acordo e o consenso racional, bem como entre uma acomodação ilusória de conflitos e a mobilização.

Essas tensões estão bastante disseminadas nos diversos fóruns de atuação da área de políticas, planejamento e gestão da Saúde Coletiva brasileira. Não temos prescindido dos posicionamentos normativos, nem daqueles apoiados em aportes teóricos que acionam dispositivos para estabelecer arranjos sociais e políticos cimentados no exercício da razão entre iguais. Portanto, a filiação a distintos enfoques teóricos, conforme assinalado pelo trabalho de Javier e Elizabeth, longe de nos embaraçar, parece ter impulsionado nosso crescimento.

Para quem se perfila, como eu, mais especificamente no campo das políticas de saúde, as dimensões do antagonismo dos interesses e seu caráter inerradicável não podem ser menosprezados $^{4}$. Daí a centralidade do poder e a necessidade de explicitação dos traços de exclusão que esculpem sua constituição. Sob esse ângulo, as preocupações são com a especificidade do político e não com a ênfase no conflito ou no consenso. A questão principal não é a da substituição da política pela ética, por uma moralidade racional ou pela economia. Não se trata de eliminar ou atenuar o poder e muito menos retroceder às posições de intolerância ou condescendência com visões, interesses e valores discordantes e sim de constituir formas de poder compatíveis com o planejamento comunicativo e com a democracia política e social.

Nesse sentido, temos muito que avançar. A inserção das ações de planejamento nas instituições públicas de saúde tem sido precária e, mais recentemente, em certos casos, orientada pelas noções meramente burocráticas de plano-documento e demonstrações físicas da implantação de unidades de saúde. No Brasil do século XXI, o Instituto de Planejamento Econômico (IPEA) retomou seu papel de catalisador da formulação de projetos. Na saúde, no que concerne particularmente à vertente industrial, logramos articular programas que envolvem o Ministério da Saúde, Fiocruz e BNDES. Certamente, o planejamento contribuirá também para encarar os desafios concernentes à preservação e reorganização da fragmentação das concepções e práticas da atenção à saúde.

\section{Referências}

1. Foucault M. A verdade e as formas jurídicas. Rio de Janeiro: Nau Editora; 2003.

2. Bobbio N. Elogio da serenidade e outros escritos morais. São Paulo: UNESP; 2002.

3. Habermas J. Verdade e justificação: ensaios filosóficos. São Paulo: Loyola; 2004

4. Mouffe C. Por um modelo agonístico de democracia. Rev. Sociol. Polít. 2005; (25):11-23. 